where he graduated in 1889. His first post was as chemist to the Pennsylvania Steel Co.; but after a year he was chosen to take charge of the research laboratory of the Illinois Steel Co. in Chicago. From that time onwards he carried out many researches on iron and steel, making great use of microscopical methods, a field in which there were still fow workers. His first paper on the microstructure of iron and steel appeared in 1893 and had many successors. In 1905, he was appointed to the chair of metallurgy at Harvard, which he occupied until his official retirement in 1935 , with an interval from 1917 until 1919, during which he acted as director of the Metallurgy Division of the Air Service in France, work recognized by his appointment as a Chevalier of the Legion of Honour.

Sauveur's investigations were concerned almost exclusively with the metallurgy of iron and steel, especially with the problems of hardening and of deformation. His contributions, elearly expressed and admirably illustrated, have played an important part in the development of the subject. In 1898 he founded a journal, the Metallographist, which became the medium for the publication of much original work from many countries. Although it lasted only for five years, being then absorbed into another journal, its volumes are often consulted by students. His text-book, "The Metallography and Heat Treatment of Iron and Steel", which first appeared in 1912, has passed through several editions, and is greatly valued. A few years ago he discussed, in the form of a dialogue, the current views on controversial questions in metallurgy.

Sauveur's department at Harvard was small in comparison with the metallurgical departments of many universities and colleges; but the quality of its work was excellent, and many of the ablest American research workers in that field received their training there. He had great charm of manner as well as great gifts of exposition, and was revered by metallurgists as one of their leaders. Even in his retirement he continued to be active, and only last year he initiated a movement with the object of simplifying the description of the microscopic constituents of steel, which he considered to have been obscured by unnecessarily complex hypotheses and cumbrous terminology.

Sauveur received many honours from technical societies, including the Bessemer Medal of the Iron and Steel Institute in 1924. He married, in 1891, Mary Prince Jones, of Massachusetts, and had two daughters.

C. H. D.

\section{Mr. Reynold Bray}

Mr. Reynold Bray, who lost his life by drowning last September, was an Arctic explorer of considerable achievement and much promise. In 1931, he was with the Oxford University Exploration Club's Expedition to Akpatok in Ungava Bay, Hudson Strait. This expedition, on which Bray was nominally photographer, made a complete survey of this hitherto little-known island. The story was told in "The Isle of Auks" by N. Polunin, 1932. In the follow- ing year Bray, with T. H. Manning, made a winter tramp through Swedish, Finnish and Russian Lapland from Bodo to Murmansk. Bray recounted this fascinating journey, which included trouble on the Soviet frontier, in "Five Watersheds" (1935). In the following year he was again with Manning, in Southampton Island and Melville peninsula mapping much of the eastern shores of those lands as well as the unknown coast of Baffin Island on the east of Foxe basin.

In 1938, Bray planned with P. Baird to continue his exploration of the western coast and the interior of Baffin Island. Ice, however, interfered with the ship's progress and eventually the two men were landed on the south-east of Melville peninsula, whence they set off in their boat last August in an attempt to reach Igloolik Island, 300 miles to the north at the eastern entrance to Fury and Hecla Strait. Some forty miles south of the island, on September 14 last year, Bray was blown out to sea in a canvas boat and lost.

\section{Mr. R. Kanthack}

The late Mr. Ralph Kanthack, who died in his seventy-seventh year at Golders Green, London, on November 12, was chiefly known for his great ability in scientific translations in English and German. He was educated in Hamburg and Lüneberg, Germany, taking an honours degree in engineering. After some period as a marine engineer, he found himself more attracted to scientific and optical studies, and became associated with Messrs. Carl Zeiss, when he had the advantage of intimate association with Abbe, Czapski and others. This led to his establishment as a London agent for Messrs. Carl Zeiss and Messrs. E. Leitz ; but in addition to business activities he was known as an authority on various aspects of microscopy.

In later years, Kanthack began the literary work which brought him well-deserved recognition. $\mathrm{He}_{\mathrm{e}}$ translated and revised a German edition of Prof. Heath's work on geometrical optics ("Lehrbuch der Geometrischen Optik". Berlin : J. Springer, 1894), and during the Great War he translated von Rohr's "The Theory of Optical Instruments" at the request of the British Government. Later, he was associated with Messrs. Adam Hilger, Ltd., for whom he prepared a book in two volumes entitled "Tables of Refractive Indices".

Mr. Kanthack was the eldest son of the late Emilio Kanthack, at one time British Consul of Para, Brazil, and brother of the late Prof. Alfredo A. Kanthack, an authority on pathology. He was much respected in optical circles for his outstanding character.

\section{WE regret to announce the following deaths:}

Prof. A. P. Coleman, F.R.S., emeritus professor of geology in the University of Toronto, an authority on Canadian metalliferous deposits, on February 27, aged eighty-six years.

Prof. Henry Louis, emeritus professor of mining and William Cochrane lecturer in metallurgy in Armstrong College, Newcastle-upon-Tyne, on February 22 , aged eighty-three years. 